\title{
SEISMIC PERFORMANCE OF RC HIGH-RISE BUILDINGS - A CASE STUDY OF 44 STOREY STRUCTURE IN SKOPJE (MACEDONIA)
}

\author{
Roberta Apostolska, Golubka Necevska-Cvetanovska, Jordan Bojadjiev, Julijana Bojadjieva
}

Preliminary notes

High-rise buildings are designed and constructed by use of modern materials and integral structural systems which are not usual for typical buildings. The existing seismic regulations act as a limiting factor and cannot cover specific behaviour of these buildings. Considering the increasing trend in their construction worldwide, additional investigations are necessary, particularly for structures in seismically active areas. It is necessary to elaborate official codes which will clearly prescribe methods, procedures and criteria for analysis and design of such type of structures. The main goal of the paper is to present a review of the existing structural systems, design recommendations and guidelines for high-rises worldwide, as well as selected results from seismic performance of 44 stories RC high-rise building which is a unique experience coming from design and construction of the four high-rise buildings in Skopje (Macedonia).

Keywords: case study; RC high-rise buildings; seismic performance; seismic regulations

Seizmičko ponašanje visokih zgrada od armiranog betona - analiza slučaja zgrade sa 44 kata u Skopju (Makedonija)

Prethodno priopćenje Visoke su zgrade projektirane i izgrađene primjenom suvremenih materijala i integralnih konstrukcijskih sustava koji nisu uobičajeni za tipične zgrade. Postojeći seizmički propisi su ograničavajući faktor i ne pokrivaju specifično ponašanje tih građevina. Uzimajući u obzir povećanje broja takvih konstrukcija u svijetu, potrebna su dodatna istraživanja, naročito u seizmički aktivnim područjima. Potrebno je izraditi službena pravila kojima će se jasno odrediti metode, postupci i kriteriji za analizu i projektiranje zgrada tog tipa. Glavni je cilj ovoga rada dati pregled postojećih konstrukcijskih sustava, preporuke za projektiranje i smjernice za visoke zgrade širom svijeta, kao i odabrane rezultate seizmičkog ponašanja zgrade od armiranog betona sa 44 kata što predstavlja jedinstveno iskustvo nastalo projektiranjem i izgradnjom četiriju visokih zgrada u Skopju (Makedonija).

Ključne riječi: analiza slučaja; seizmičko ponašanje; seizmički propisi; visoke zgrade od armiranog betona

\section{Introduction}

Intensive migration of people and concentration of material resources in urban megalopolises imposes new modern concepts of construction of residential and administrative structures. In most of the cases, such buildings are designed and constructed by use of modern materials and integrated structural systems which are not usual for typical buildings. Demand of the high-rise buildings is huge where there is a lack of construction area but also they could serve as a symbol of economic power.

There is no universally accepted definition for highrise building. The most reasonable engineering approach is to measure its largest aspect ratio; however the limits are not defined yet [1]. According to the Pacific Earthquake Engineering Research Center's Tall Buildings Initiative (PEER-TBI) Guideline of 2010 [2], the building with fundamental period height $>>1 \mathrm{sec}$ and significant mass participation in higher modes is defined as tall building. The Los Angeles Tall Buildings Structural Design Council (LATBSDC) Guideline of 2014 [3] defines high-rise building as building whose height is $>$ $160 \mathrm{ft}$.

Considering the increasing worldwide trend in construction of this type of structures, need occurs for establishment of regulations, guidelines, instructions that will extensively facilitate the design in engineering practice. The existing seismic regulations act as a limiting factor and cannot cover specific behaviour of high-rise buildings. Even the most developed countries in the world have so far not issued an official standard (regulation) for design of high-rises in seismically active areas. The most advanced ones coming from the United States are the
PEER-TBI Guideline [2] and the LATBSDC Guideline of 2014.

In the leading world economies construction of highrises instead of trend becomes more and more everyday design practice. However this is not a case in the Balkan region. Design and construction of four reinforced concrete buildings, each with 44 stories started recently in Skopje. These buildings will be the highest ones not only in Macedonia but in the region as well and will open a new era in the regional engineering practice. The main goal of this paper is to share the unique experience in this field and to contribute to its application in the regional construction practice. Presented further in the paper is review of the existing structural systems, design recommendations and guidelines for high-rises worldwide, as well as selected results from seismic design of 44 stories RC high-rise building.

\section{Review of integrated structural systems, guidelines and design practice of RC high-rise buildings}

Most of the high-rises, designed and constructed worldwide, have integrated structural systems like core wall, shear wall - frame, frame tube, connected tubes, tube system with perimeter vertical bracings etc. (Fig. 1).

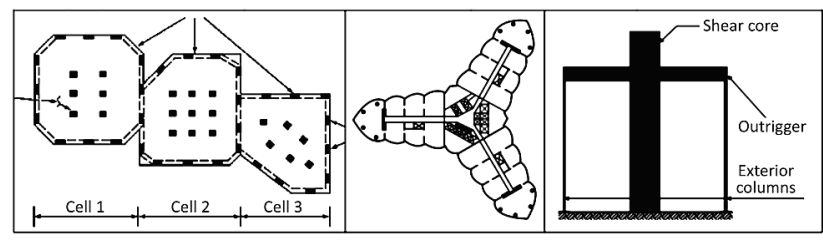

Figure 1 Structural system classification 
Fig. 2 shows types of structural systems depending on number of stories for seismically inactive areas, while Tab. 1 presents types of structural systems applicable in seismically active regions along with the level of their stiffness, strength and ductility ( $\mathrm{L}-$ low, $\mathrm{M}-$ medium and $\mathrm{H}-$ high).

Concerning design codes, for over half a century the implicit objective of prescriptive building codes has been to produce buildings which resist minor earthquakes with little or no structural damage; moderate earthquakes with repairable structural damage; and major earthquakes with severe structural damage but no loss of life [1]. Engineers have been brought up to believe that if they follow the code prescriptive rules, the objectives will be automatically achieved. Unfortunately, many recent earthquakes proved the opposite which triggered elaboration of performance based design codes.

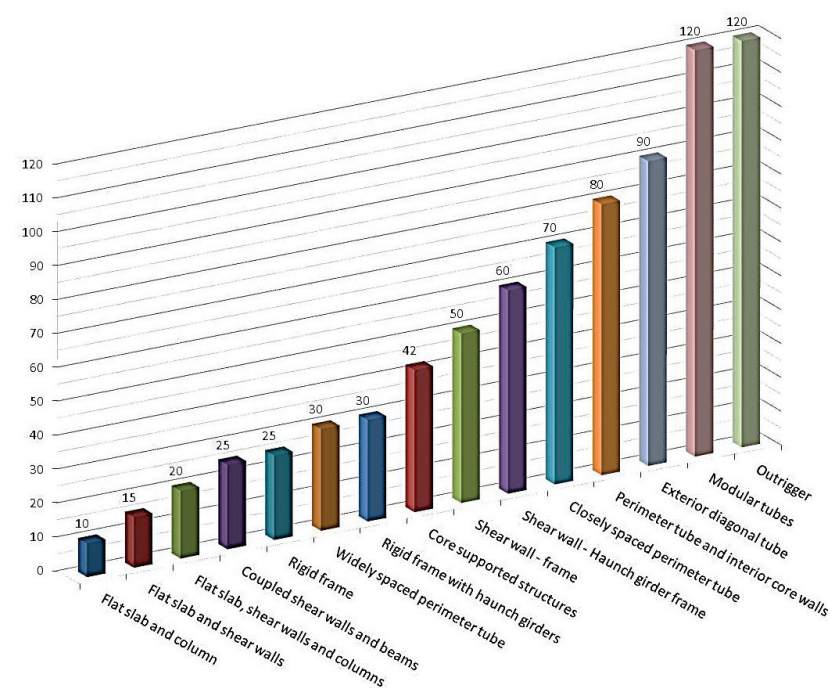

Figure 2 Classification of structural systems based on their height

Table 1 Structural systems in seismically active regions

Table 1 Structural systems in seismically active regions
\begin{tabular}{|l|c|c|c|c|}
\hline \multicolumn{1}{|c|}{ System type } & Stiffness & Strength & Ductility & $\begin{array}{c}\text { Max no } \\
\text { of stories }\end{array}$ \\
\hline Rigid frame & L & H & H & $15 \div 20$ \\
\hline Braced frame & H & H & $\mathrm{L} \div \mathrm{M}$ & $20 \div 30$ \\
\hline Structural walls & H & H & $\mathrm{L} \div \mathrm{M}$ & $25 \div 30$ \\
\hline Hybrid frame & H & H & $\mathrm{M} \div \mathrm{H}$ & $30 \div 40$ \\
\hline Core and outrigger system & $\mathrm{H}$ & $\mathrm{H}$ & $\mathrm{L} \div \mathrm{M}$ & $50 \div 60$ \\
\hline Frame tube system & $\mathrm{H}$ & $\mathrm{H}$ & $\mathrm{M} \div \mathrm{H}$ & $60 \div 70$ \\
\hline Tube in tube & $\mathrm{H}$ & $\mathrm{H}$ & $\mathrm{M} \div \mathrm{H}$ & $70 \div 80$ \\
\hline Trussed tube & $\mathrm{H}$ & $\mathrm{H}$ & $\mathrm{M} \div \mathrm{H}$ & $80 \div 100$ \\
\hline Modular tube system & $\mathrm{H}$ & $\mathrm{H}$ & $\mathrm{M} \div \mathrm{H}$ & $120 \div 150$ \\
\hline
\end{tabular}

However, while in certain countries (for example Japan and China), there are strict design principles based on "performance-based" methodology, many other countries do not, at all, have regulations that are beyond the limits of the traditional design principles valid for the ordinary buildings. Some of the reasons why these regulations are not appropriate for seismic design of highrises are: they are developed for low and medium-high buildings (most frequently frame systems) with dominant first mode behaviour; they limit the possibility for innovation which is important in high-rises which are by themselves unique and require an original approach; the codes are based on elastic methods of analysis but for prediction of forces, the relative story displacements and the accelerations of the high buildings that occur as a result of inelastic behaviour, nonlinear methods must be used.

In order to fill this gap in the USA, Tall Buildings Initiative [2] was launched for the purpose of increase of information and recommendations in the existing regulations, for the parts referring to design of high-rise buildings. Since 2005, several documents have been issued in the form of recommendations for analysis and design of high buildings in seismically active regions. Their aim is to add, within the frames of the recommendations in the existing codes, important aspects of seismic design of high buildings, including definition of site response spectra, procedures for analysis as well as acceptability criteria $[2,3,4]$.

\section{Seismic performance of RC high-rise buildings in the Balkan region - case study - 44 story building in Skopje}

Presented further is analysis and design of one of the highest buildings in the region - Cevahir Sky City complex in Skopje (Fig. 3) [5, 6, 7]. The structure is located in a highly seismic environment. During analysis, design and verification of the seismic resistance of the structure, in addition to EN1992 [8] and EN1998 [9], the recommendations and procedures for design of high rises were used as follows:

- An alternative procedure for seismic analysis and design of tall buildings located in Los Angeles region, A consensus document, Los Angeles Tall Buildings Structural Design Council, 2008 Edition with supplement \# 1 [3].

- Tall Building Initiative: Guidelines for Performance Based Seismic Design of Tall Buildings, PEER Report 2010/05 [2].

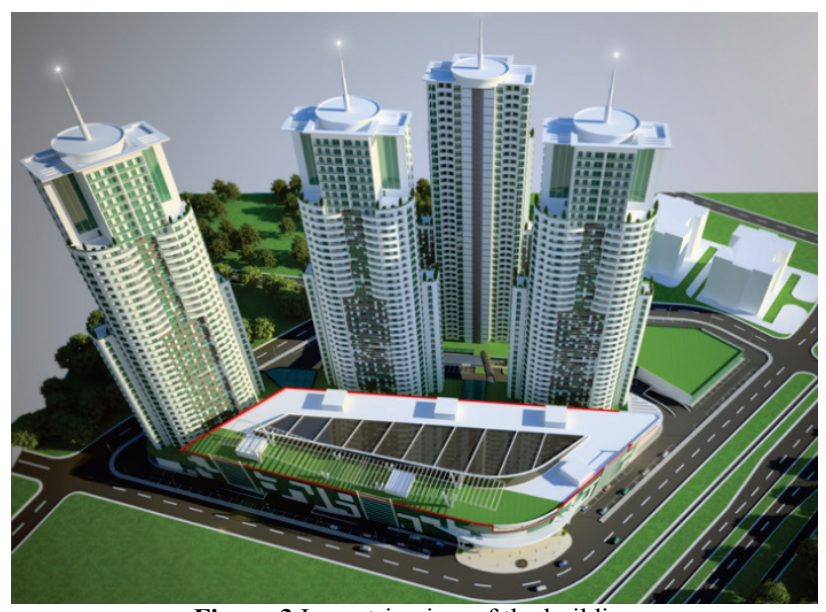

Figure 3 Isometric view of the building

\subsection{Structural system}

The structural system is designed as a reinforced concrete structure - a system of shear walls (Fig. 4). The building is designed to have two basements and 42 stories. The floor plan dimensions at level $+235,01 \mathrm{~m}$ are $55,90 \mathrm{~m}$ in $x-x$ direction and $24,25 \mathrm{~m}$ in $y-y$ direction. The total height of the structure is $134,5 \mathrm{~m}$. The floor slab is with a thickness of $20 \mathrm{~cm}$. The thickness of the walls is 
variable and it amounts to $40 \mathrm{~cm}, 30 \mathrm{~cm}$ and $25 \mathrm{~cm}$. The foundation structure is designed on piles interconnected by a pile cap with a thickness of $175 \mathrm{~cm}$.

\subsection{Seismic design parameters}

In-situ measurements and analytical surveys were carried out for the needs of defining the seismic potential of the site for the High Rise Buildings "Makedonya Chevahir Resident" [10]. Based on seismic risk analysis, the maximum acceleration has been given as a seismic parameter for two seismic risk levels: design and maximum expected earthquake for the given location.

For the design level the maximum acceleration should be $0,30 \mathrm{~g}$ and for the maximum expected earthquake it should be $0,35 \mathrm{~g}$. Results from site response analysis show that dynamic amplification factor is varying in the range of 1,10 to 1,20 . That means that the amplitude of the seismic excitation at the surface will be slightly higher than in respect to the corresponding excitation at the level of seismic bedrock [10].

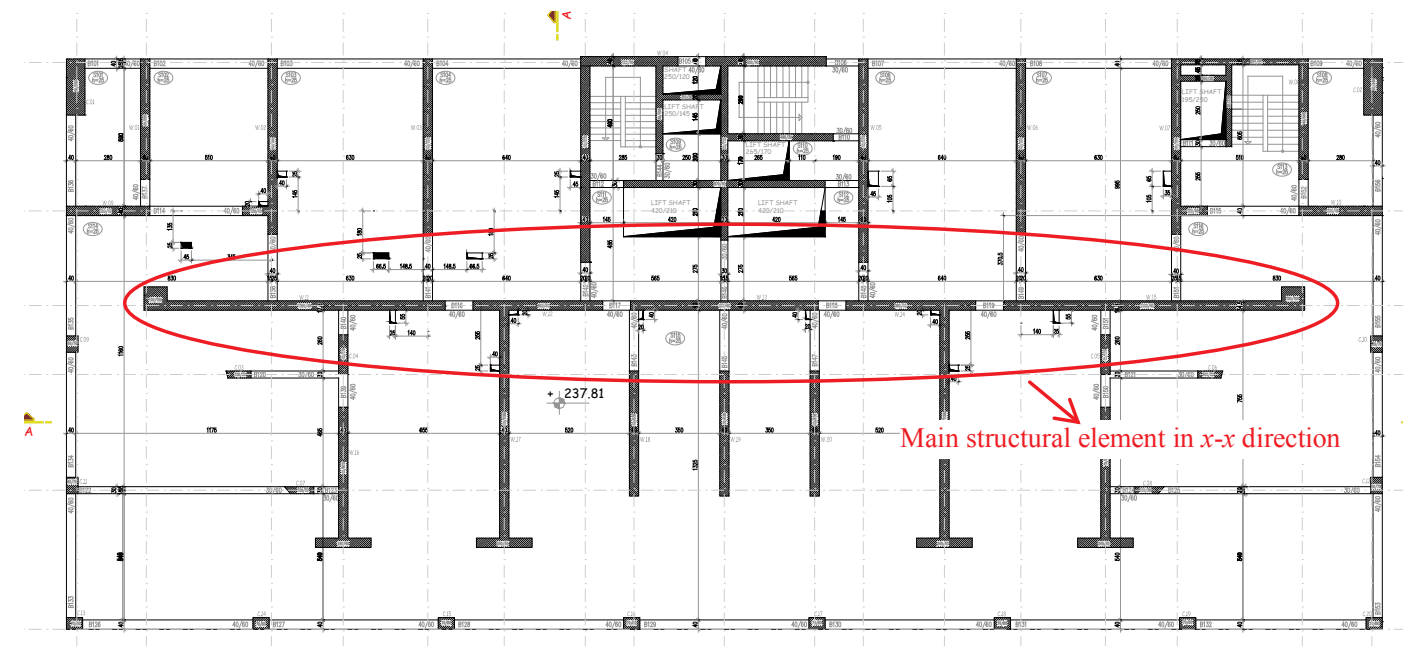

Figure 4 Floor plan of the structure at the level $+235,01 \mathrm{~m}$

\subsection{Seismic resistance of 44 story building}

Analysis of the structure was carried out in three phases. In the first phase, the structure was analysed in the linear (elastic) range using ETABS computer software [11], while in the second phase, a nonlinear static ("push over") analysis was made by means of the SAP2000 [12]. In the third phase, nonlinear dynamic analyses were carried out to define the seismic resistance of the structure for expected actual seismic effects at the design location [13].

Taking into account all the recommendations and procedures for design of such type of structures, the building structure was designed to satisfy the following design criteria:

- no-collapse requirement - whereat the structure should be designed for input seismic effect with a return period of 475 years, without local or global failure

- damage limitation requirement - whereat the structure should be designed for input seismic effect with a return period of 95 years, without damage and disruption in functioning

Presented further are selected results from the carried out analyses.

\subsubsection{Linear elastic analysis}

Linear elastic analysis was done by application of the computer software ETABS and design spectrum in accordance with EN1998. Two different mathematical models were created: fixed base model and model with inlcuded piles and pile cap. The periods of the structure are $T_{x}=2,2077 \mathrm{sec}$ and $T_{y}=3,2267 \mathrm{sec}$ (Fig. 5). The total horizontal displacements in $x-x$ direction are $11.79 \mathrm{~cm}$ and in $\mathrm{y}-\mathrm{y}$ direction, this amounts to $25,09 \mathrm{~cm}$. The max. value of the interstorey displacements in $x$ - $x$ direction is $0,34 \mathrm{~cm}$ and in $y-y$ direction $0,86 \mathrm{~cm}$. All the parameters are in accordance with the max. allowed ones.

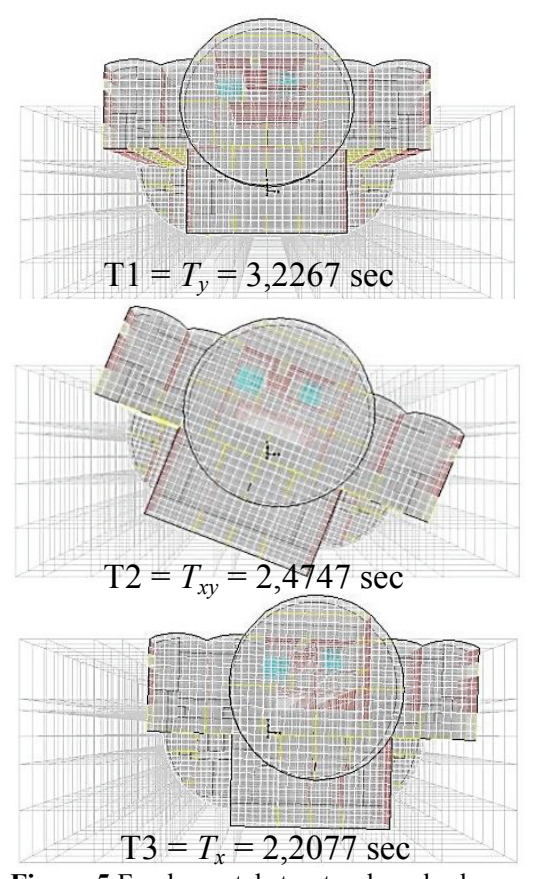

Figure 5 Fundamental structural mode shapes 


\subsubsection{Non-linear static (push-over) analysis}

Nonlinear static analysis was done by application of the "push over" method incorporated in the SAP2000 computer software. As a result of this analysis in two orthogonal directions, values of structural response were obtained expressed through the total shear force at the base and maximum horizontal displacement of the top, (Fig. 6). Presented further are selected results for the main structural element in $x-x$ direction-central frame which bears $80 \%$ of the total seismic force in this direction (marked in Fig. 4).

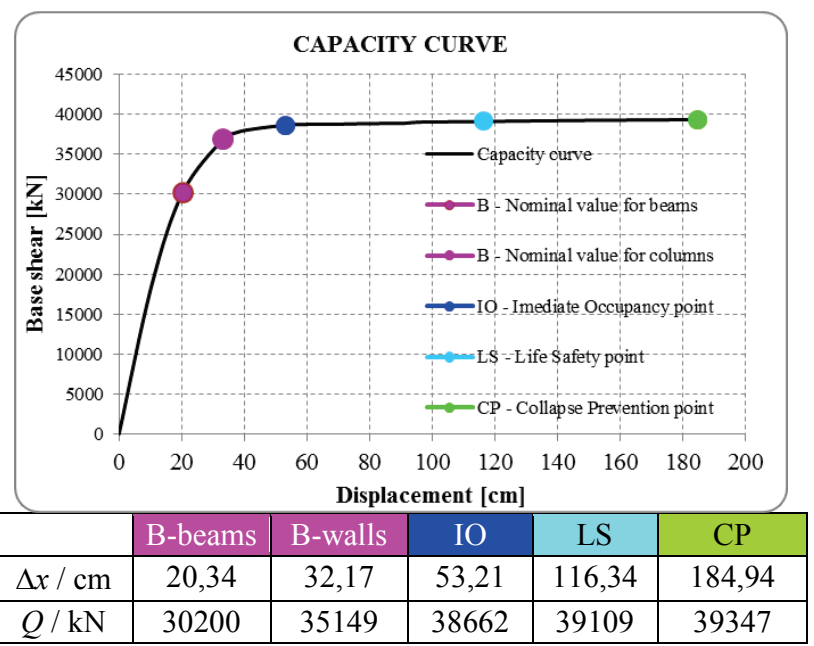

Figure 6 Base shear force and maximum top displacement

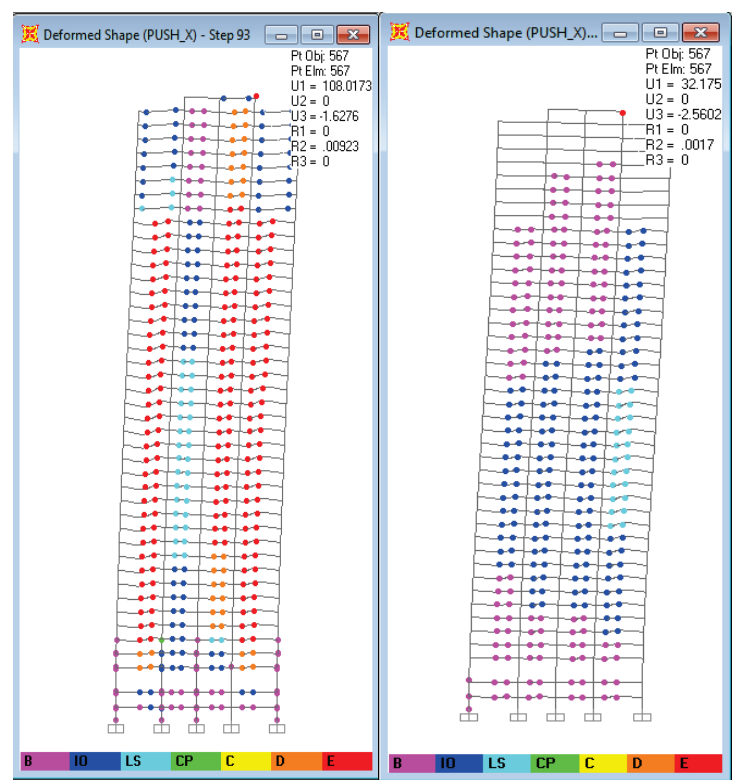

Figure 7 Plastic hinge formation

For displacements of up to $20,34 \mathrm{~cm}$, the plastic hinges are concentrated in the beams immediately before point $\mathrm{B}$ of the capacity curve, i.e., the system is in the elastic range. For a displacement of $32,17 \mathrm{~cm}$, the first plastic hinges occur. At the level of the top displacement equal to $53.21 \mathrm{~cm}$ plastic hinges occur in the zone of point "IO (immediate occupancy)" of the capacity curve, which shows that the structure may suffer damage at these displacements, but the damage is repairable. For maximum displacement at the top of $115,34 \mathrm{~cm}$, nonlinearity is concentrated in almost all the beams, even with occurrence of plastic hinges in the zone of point "LS (life safety)" of the capacity curve, as well as occurrence of plastic hinges in the walls of zone "IO (immediate occupancy)" which shows that the structure may suffer damage, but there is no danger of loss of human lives (Fig. 7).

The performance point which is intersection between demands expressed via EN1998 design spectra for the given location and structural capacity curve is presented in Fig. 8, for two different levels of peak ground acceleration (PGA) according to the design requirements.

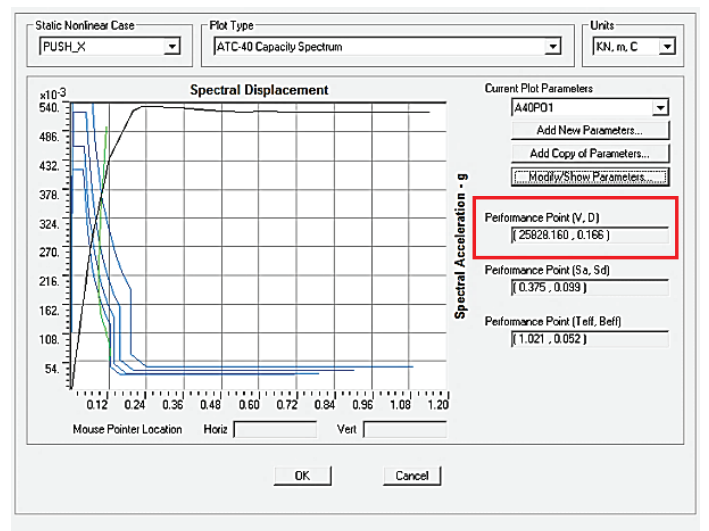

a) for acceleration level $0,22 \mathrm{~g}$ (damage limitation)

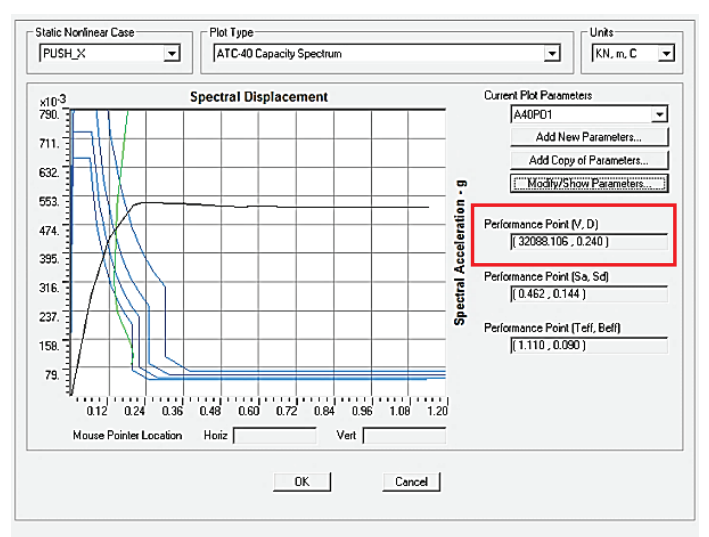

b) for acceleration level $0,35 \mathrm{~g}$ (no-collapse)

\begin{tabular}{|c|c|c|c|}
\hline & $0,22 \mathrm{~g}$ & $0,35 \mathrm{~g}$ & comment \\
\hline$\Delta x / \mathrm{cm}$ & 16,60 & 24,00 & elastic range \\
\hline$Q / \mathrm{kN}$ & 25828 & 32088 & near yielding point \\
\hline
\end{tabular}

The obtained results show that the structure satisfied design criteria i.e. for $P G A=0,22 \mathrm{~g}$ it will behave elastically and for the $P G A=0,35 \mathrm{~g}$, the nonlinearity will start.

In order to have better understanding of the behaviour of the structure, presented further is comparison among relative story displacements obtained from push-over analysis for all four characteristics points of the capacity curve $(\mathrm{B}, \mathrm{IO}, \mathrm{LS}, \mathrm{CP})$, requirements from the existing national regulation and allowed displacements recommended by PEER and LATBSDC (Fig. 9). The latest ones are

- $\quad 0,5 \%$ of story height for frequent earthquake (return period of 43 years)

- $2,0 \%$ of story height for design earthquake (return period of 475 years)

- $3,0 \%$ of story height for maximum expected earthquake (return period of 2475 years). 


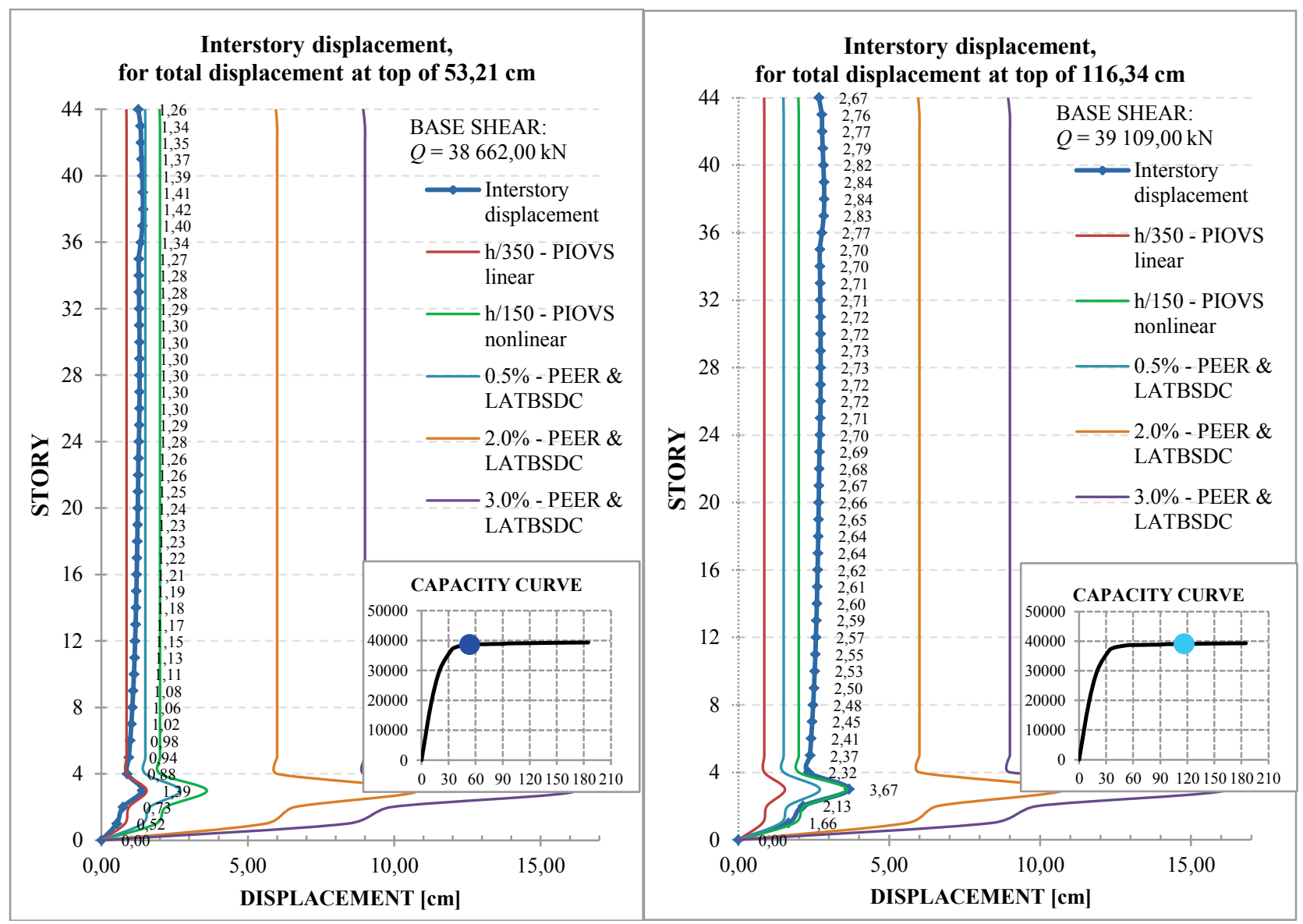

Figure 9 Interstory displacements from nonlinear push-over analysis

\subsubsection{Non-linear dynamic time history analysis - NLTHA}

The nonlinear dynamic analysis was performed using methodology developed at IZIIS, Skopje [13]. Definition of the dynamic response of the structure means solving of the dynamic equation of motion of the system and computation of the parameters (displacement, velocity and acceleration) of the system during an earthquake effect.

The main dynamic structural model is idealized "shear-type" model and represents a fixed-based schematized system of $n$ concentrated masses along height of the stories that are connected by joints allowing displacement only in horizontal direction. Analyses were carried out for set of 10 different earthquake registrations in order to simulate real near and far field events.

From the obtained results it can be concluded that the maximum relative displacements in $x$ - $x$ direction are around $1,50 \mathrm{~cm}$, while in $y-y$ direction, these range about $1,80 \mathrm{~cm}$, which is lower than the allowed story displacements $h / 150$ according to national regulation (Fig. 10). The obtained displacements are also less than allowed displacements recommended by PEER and LATBSDC for design level earthquake $(2 \%$ of the story height). The maximum required ductilities in longitudinal direction are around 3,0, while in y-y direction, they range to maximum 2,1, which is acceptable for such type of structures. Presented further are selected results from the nonlinear dynamic analysis.

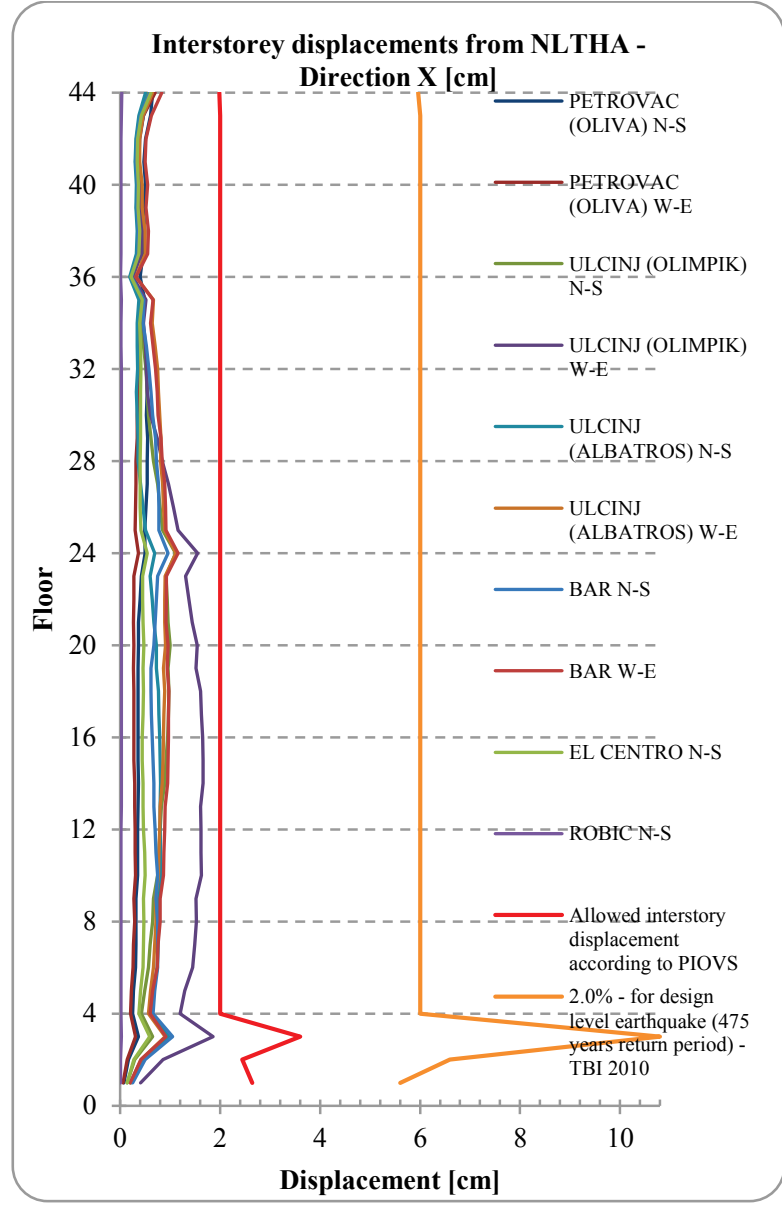

Figure 10 Interstory displacements from the NLTHA analysis 


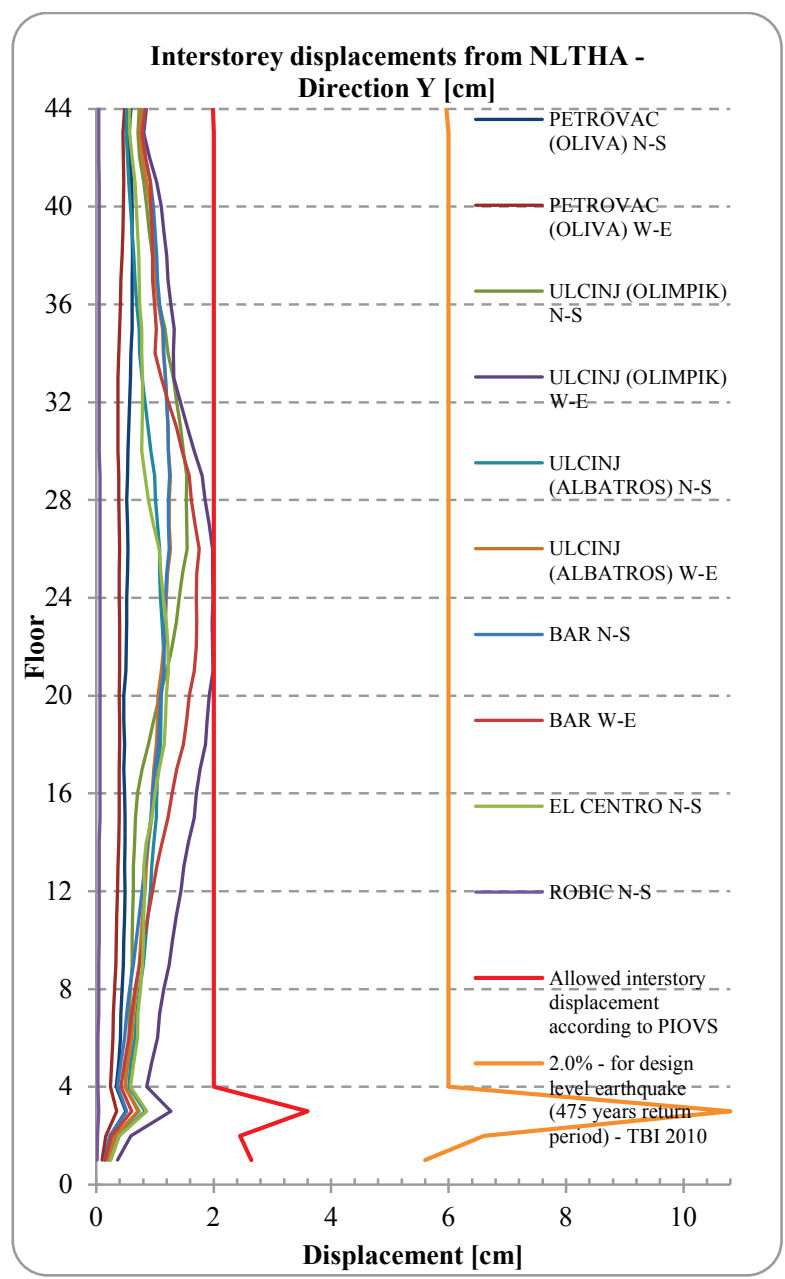

Figure 10 Interstory displacements from the NLTHA analysis (contd.)

As a result of the ample analytical investigations in the linear and nonlinear range of the high-rise $\mathrm{RC}$ building with 44 stories, it can be concluded that the structure exhibits a favourable dynamic behaviour in both linear and nonlinear range. It is generally concluded that the structure has a sufficient bearing and deformability capacity for the seismic effects expected on the site.

\subsubsection{Details from the construction phase}

The total size of the construction site is more than $200000 \mathrm{~m}^{2}$. At the moment three of four of high-rises are already finished. Some photos from the construction are given below (Fig. 11).

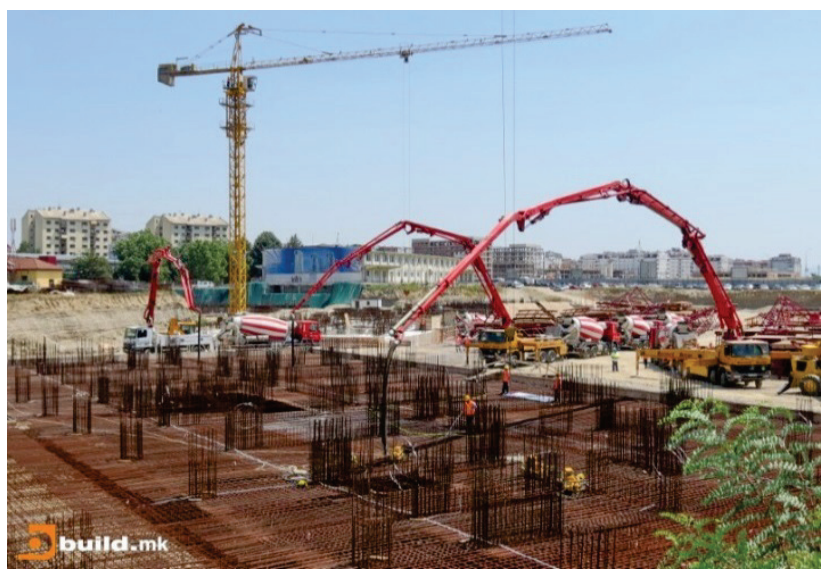

Figure 11 Photos from the construction phase

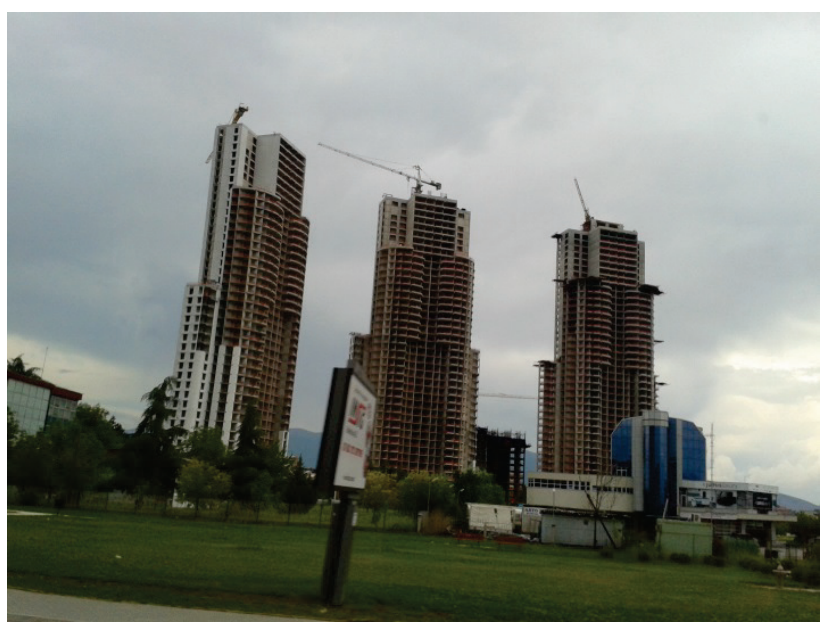

Figure 11 Photos from the construction phase (contd.)

\section{Conclusion}

Intensive migration of people and concentration of material resources in urban megalopolises impose new modern concepts of construction of residential and administrative structures. In most of the cases, such buildings are designed and constructed by use of modern materials and integrated structural systems which are not usual for typical buildings.

The unique experience coming from design, analysis and construction of the four 44 stories high-rise buildings in Skopje, Macedonia is presented in the paper. The structural system is designed as a reinforced concrete structure - a system of shear walls. The foundation structure is designed on piles interconnected by a pile cap. The building structure was designed to satisfy two design criteria: no-collapse requirement and damage limitation requirement.

Analysis of the structure was carried out in three phases. In the first phase, the structure was analysed in the linear (elastic) range using ETABS computer software [11], while in the second phase, a nonlinear static ("push over") analysis was made by means of the SAP2000 [12]. In the third phase, nonlinear dynamic analyses were carried out to define the seismic resistance of the structure for expected actual seismic effects at the design location [13]. The results show favourable seismic performance of analysed case study.

Based on the case study described, structural coupled wall systems could be recommended as a favourable and economical solution for design of high-rise up to 50 stories and preferably for residential and administrative buildings. RC structural walls have big in-plane stiffness and strength which makes them ideal for stabilization of high-rise buildings. The main seismic elements are RC coupled walls which are resistant to shear forces and reduce structural deformations.

Performed investigation shows that the existing seismic regulations are limiting and cannot cover the specificities of behaviour of high-rises. Considering the increasing trend in construction of this type of structures worldwide, additional investigations are necessary, particularly for structures in seismically active areas. It is necessary to elaborate official codes which will clearly prescribe methods, procedures and criteria for analysis and design of such type of structures. Particular attention 
should be paid to monitoring of these structures during construction and in the course of their serviceability life. Development of corresponding computer tools for as realistic as possible definition of the seismic resistance of high buildings that are efficient to be used in engineering practice are also necessary for as better as possible design of high-rises.

\section{References}

[1] Naeim F. Performance based seismic design of tall buildings. // Proceedings of the $14^{\text {th }}$ European Conference of Earthquake Engineering/ Ohrid, 2010, Keynote lecture. DOI: 10.1007/978-90-481-9544-2_7

[2] PEER. Tall Building Initiative. Guidelines for performancebased seismic design of tall buildings, 2010.

[3] Los Angeles Tall Buildings Structural Design Council. An Alternative Procedure for Seismic Analysis and Design of Tall Buildings Located in the Los Angeles Region, 2011.

[4] Structural Engineers Association of Northern California (SEAONC). Recommended Administrative Bulletin on Seismic Design \& Review of Tall Buildings Using NonPrescriptive Procedures, 2007.

[5] Garevski, M.; Necevska-Cvetanovska, G.; Apostolska, R. Final report of the on revision of the final executive design (structural engineering phase) for CEVAHIR high-rise buildings, Blocks A, B, C and D, IZIIS Reports, 2012.

[6] Bojadjiev, J. Seismic Performance of Reinforced Concrete High-Rise Buildings. // Master Thesis, Skopje, October 2012.

[7] Azhdary, F.; Shabakhty, N. Performance Based Design and Damage Estimation of Steel Frames with Consideration of the Uncertainties. // Tehnicki Vjesnik-Technical Gazette. 21, 2(2014), pp. 351-358.

[8] CEN TC/250. EN1992-1-1: Design of concrete structuresPart 1-1: General rules and rules for buildings, December, 2004.

[9] CEN TC/250. EN 19981-1: Design of structures for earthquake resistance - Part 1-1: General rules, seismic actions and rules for buildings, July 2009.

[10] Sesov, V. et al. Evaluation of the seismic potential of the site: Definition of the seismic design parameters for High Rise Buildings- Project: MAKEDONYA CEVAHIR RESIDENT, IZIIS Report 2011/24.

[11] ETABSv9.7.2. Integrated Analysis, Design and Drafting of Building Systems, CSI, Berkley University California, 2010.

[12] SAP2000v14.2.3 Advanced Structural Analysis Program Wilson and Habibullah, CSI, Berkley University, California, 2010.

[13] Necevska-Cvetanovska, G.; Apostolska R. Methodology for Seismic Design of R/C Building Structures. // Proceedings of the $12^{\text {th }}$ World Conference on Earthquake Engineering / New Zealand, 2010.

\section{Authors' addresses}

Roberta Apostolska, Professor, Doctor

University of Cyril and Methodious, Institute of Earthquake Engineering and Engineering Seismology (IZIIS) Todor Aleksandor str. 165, 1000 Skopje, Republic of Macedonia E-mail: beti@pluto.iziis.ukim.edu.mk

Golubka Necevska-Cvetanovska, Professor, Doctor University of Cyril and Methodious, Institute of Earthquake Engineering and Engineering Seismology (IZIIS)

Todor Aleksandor str. 165, 1000 Skopje, Republic of Macedonia E-mail: golubka@pluto.iziis.ukim.edu.mk

Jordan Bojadjiev, M.Sc., Doctoral student University of Cyril and Methodious, Institute of Earthquake Engineering and Engineering Seismology, IZIIS

Todor Aleksandor str. 165, 1000 Skopje, Republic of Macedonia E-mail: bojadjiev@gmail.com

\section{Julijana Bojadjieva, M.Sc., Doctoral student}

University of Cyril and Methodious, Institute of Earthquake Engineering and Engineering Seismology, IZIIS

Todor Aleksandor str. 165, 1000 Skopje, Republic of Macedonia E-mail: jule@pluto.iziis.ukim.edu.mk 